Eur. J. Clin. Chem. Clin. Biochem.

Vol. 29, 1991, pp. 717-724

(C) 1991 Walter de Gruyter \& Co.

Berlin - New York

\title{
Liquid Preservation of Polymorphonuclear Leukocytes: Effect of Various Additives on Chemotaxis Preservation
}

\author{
By L. Verstraeten, M. Marchand-Arvier, F. Schooneman and C. Vigneron \\ Centre régional de transfusion sanguine de Nancy-Brabois, Vandoeuvre-les-Nancy, France
}

(Received January 14/July 17, 1991)

Summary: Adequate storage of polymorphonuclear leukocytes would allow an easier in vitro study of their structure and their functions, an easier study of polymorphonuclear leukocyte diseases (e.g. chronic granulomatous disease) and an easier use of polymorphonuclear leukocytes as a clinical tool (e.g. for localizing infections). Unfortunately, polymorphonuclear leukocytes are nearly impossible to preserve, even in shortterm storage. This study proposes a model for the study of polymorphonuclear leukocyte storage in a synthetic medium: Plasmion ${ }^{\oplus}$.

For storage over a period of $24 \mathrm{~h}$, we found that supplementation with each of the following additives: bicarbonate buffer, glucose, adenosine triphosphate (ATP), ascorbic acid, nicotinamide adenine dinucleotide $(\mathrm{NADH})$, nicotinamide adenine dinucleotide phosphate (NADPH), $\alpha$-tocopherol acetate, amikacin and ampicillin, significantly improves $(p<0.05)$ one or several functions of the polymorphonuclear leukocytes.

When samples were stored for $48 \mathrm{~h}$, we found that the addition of bicarbonate buffer after $24 \mathrm{~h}$ significantly improves the maintenance of several functions of polymorphonuclear leukocytes, in particular chemotaxis.

Preservation for $96 \mathrm{~h}$ was achieved by making additions of supplements on each day of storage, with a chemotaxis maintenance of $83 \%$ at $24 \mathrm{~h}, 59 \%$ at $48 \mathrm{~h}, 46 \%$ at $24 \mathrm{~h}$ and $20 \%$ at $96 \mathrm{~h}$.

In conclusion, by using the Plasmion ${ }^{\otimes}$ medium, and adding the above-mentioned compounds on each day of storage, chemotaxis can be satisfactorily maintained over 4 days.

\section{Introduction}

Adequate storage of polymorphonuclear leukocytes would allow an easier in vitro study of their structure and functions, an easier study of polymorphonuclear leukocyte diseases (e.g. chronic granulomatous disease) and an easier use of polymorphonuclear leukocytes as a clinical tool (for transinfusion or for localizing infections). Polymorphonuclear leukocyte preservation sets numerous problems and hitherto no successful solution has been found. Even though no adequate approach has been proposed for this type of storage, important infornation is currently emerging. Neither premedication with glucocorticoids nor granulocyte collection with continuous or intermittent flow centrifugation significantly alters the storage of the polymorphonuclear leukocytes transfusion bag
(1). Several storage condition studies suggest that optimal storage is achieved at a $\mathrm{pH}$ close to 7.4 , at room temperature $\left(20-24^{\circ} \mathrm{C}\right)$, with no agitation, and with adequate glucose supplementation $(2-4)$. Several methods have been used to evaluate the impairment of polymorphonuclear leukocyte functions during storage $(2-4)$. Chemotaxis seems the most sensitive indicator of polymorphonuclear leukocyte damage in this case $(2-4)$.

In this report, we attempted to extend polymorphonuclear leukocyte storage to 4 days, using a liquid preservation model supplemented with several compounds. We studied the influence of these additives on polymorphonuclear leukocyte functions, in particular chemotaxis. 


\section{Material and Methods}

\subsection{Granulocyte collection}

\subsubsection{Phlebotomy'}

Donors were selected according to French blood donation norms (1). The subjects were not premedicated with steroids (1). The whole blood was obtained by phlebotomy and was drawn into a sterile polypropylene tube (Falcon 2059, Becton Dickinson, USA) containing $10 \times 10^{3} \mathrm{IU} / \mathrm{l}$ blood heparin (Héparine Eurobio, France).

\subsubsection{Granulocj'te isolation}

All solutions were sterilized by filtration (Cathivex S $0.22 \mu \mathrm{m}$ filter, Millipore, France) and all manipulations were performed under a laminar air flow hood (Gelaire BSB4, USA). Polymorphonuclear leukocytes were isolated from whole blood by sedimentation using a solution of $20 \mathrm{~g}$ dextran $\mathrm{T} 500$ (Pharmacia, Sweden) per liter in a $0.15 \mathrm{~mol} / \mathrm{l}$ aqueous sodium chloride. Red blood cells were haemolysed with $0.15 \mathrm{~mol} / \mathrm{l}$ ammonium chloride solution (Merck, West Germany) for $10 \mathrm{~min}$ at $4^{\circ} \mathrm{C}$. The suspension was then centrifuged for $10 \mathrm{~min}$ at $250 \mathrm{~g}$ and at $4{ }^{\circ} \mathrm{C}$ using a Minifuge centrifuge (Heraeus Christ, West Germany) and the supernatant fraction was removed. The cells were washed twice with $1 \mathrm{mmol} / \mathrm{l}$ glucose phosphate buffer $\mathrm{pH}$ 7.4), then resuspended in $5 \mathrm{ml}$ of storage medium contained in a sterile polypropylene tube (Falcon 2059, Becton Dickinson, USA). The cells were counted using a $\mathrm{S}+$ counter (Coulter, USA).

\subsection{Storage procedure}

Polymorphonuclear leukocytes were stored at room temperature, under several different conditions $(2-4)$. The temperature was accurately recorded for each assay.

The storage medium was Plasmion ${ }^{\circledR}$, an injectable gelatin solution with an electrolyte content close to that of plasma, but without calcium ions (Laboratoire Roger Bellon, France).

We supplemented the storage medium with several compounds

a) sodium bicarbonate (Gibco, UK) $9 \mathrm{mmol} / \mathrm{l}$ was used to buffer the storage medium close to $\mathrm{pH} 7.4$;

b) glucose (Prolabo, France) $5.5 \mathrm{mmol} / \mathrm{l}$ and adenosine triphosphate (ATP) (Boehringer Mannheim, Germany) $1 \mu \mathrm{mol} / 1$ were used to obtain an adequate energetic medium for polymorphonuclear leukocytes;

c) calcium chloride (Prolabo, France) $2 \mathrm{mmol} / 1$ was used to study the damage to polymorphonuclear leukocytes caused by this ion (5);

d) ascorbic acid (Laroscorbine, Roche, Switzerland) $10 \mu \mathrm{mol} / \mathrm{l}$, nicotinamide adenine dinucleotide (NADH) (Boehringer Mannheim, Germany) $1 \mu \mathrm{mol} / \mathrm{l}$, nicotinamide adenine dinucleotide phosphate (NADPH) (Boehringer Mannheim, Germany) $1 \mu \mathrm{mol} / 1$ and $\alpha$-tocopherol acetate suspension (Ephynal ${ }^{\otimes}$, Roche, Switzerland) $46 \mu \mathrm{mol} / \mathrm{l}$ were used because a relatively reducing storage medium seems to be advantageous (6);

e) amikacin (Amiklin ${ }^{\oplus}$, Bristol, France) $34 \mu \mathrm{mol} / 1$ and ampicillin (Totapen ${ }^{\circledast}$, Bristol, France) $41 \mu \mathrm{mol} / 1$ were used to avoid bacterial contamination during storage.

All these additives were sterilized by filtration (Cathivex 0.22 $\mu \mathrm{m}$ filter, Millipore, France).

We compared Plasmion ${ }^{\circledR}$ with another storage medium: RPMI (Roswell Park Memorial Institute) 1640 containing HEPES 25 $\mathrm{mmol} / \mathrm{l}$ and glutamine (Gibco, UK), because this storage medium has been successfully used by other authors (7). The agitation assay was performed with a rotary agitator (speed:
$20 \mathrm{~min}^{-1}$; diameter of the plate: $20 \mathrm{~cm}$ ). The light assay was performed using a neon light (Mazda fluor, France) situated $60 \mathrm{~cm}$ away from the polymorphonuclear leukocytes storage medium.

Endotoxin was determined with the IBF kit (IBF, France). Leukocyte, polymorphonuclear leukocyte, erythrocyte and platelet counts were performed with a $S+$ counter (Coulter, USA).

\subsection{Methods used to study polymorphonuclear leu-} kocytes functions

Random migration and chemotaxis towards the synthetic peptide formyl-methionyl-leucyl-phenylalanine $0.1 \mu \mathrm{mol} / \mathrm{l}$ (Sigma, USA) were performed using a migration under agarose method according to Nelson et al. (8). The nitroblue tetrazolium reduction test with latex particles was performed according to Béaud et al. (1). One hundred granulocytes were counted to determine the percentage of nitroblue tetrazolium-positive polymorphonuclear leukocytes (more than 10 latex particles phagocytosed with nitroblue tetrazolium reduction) and the percentage of phagocyte-positive polymorphonuclear leukocytes (more than 10 latex particles phagocytosed). Intragranulocytic ATP determination was performed by a bioluminescent assay according to the LKB determination kit for ATP (LKB, Finland). The extraction of ATP was performed according to Thore (9). Intragranulocytic ATP was expressed in $\mathrm{nmol} / 10^{6}$ polymorphonuclear leukocytes. Chemoluminescence after stimulation by pre-opsonized zymosan (1) was determined according to the LKB method (LKB, Finland), with luminol $100 \mu \mathrm{mol} / 1$.

Average and maximum light emission were expressed in $\mathrm{V} / \mathrm{s} \cdot 10^{6}$ polymorphonuclear leukocytes. The $\mathrm{pH}$ level of the polymorphonuclear leukocyte storage medium was determined using a TS 40/N pH meter (Tacussel électronique, France). Lysozyme $^{1}$ ) was assayed with the Eurobio kit (Eurobio, France) and the results were expressed in $\mathrm{mg} / \mathrm{l}$. $\beta$-Glucuronidase ${ }^{1}$ ) was assayed with the Sigma kit (Sigma, USA) and the results were expressed in Sigma Units per litre. All these methods, commonly used for this type of study, show a good accuracy and a good precision (variation coefficient lower than $10 \%$ ).

\subsection{Experimental design}

Each assay result following supplementation with an additive depends on the polymorphonuclear leukocyte conservation achieved with the earlier additives. The order of addition was based on the analysis of the relevant literature: the most important additive, bicarbonate buffer, was tested first, and then glucose.

\subsubsection{4 h preservation (assay $I$ to $X I$ )}

Polymorphonuclear leukocyte functions: chemotaxis, random migration, nitroblue tetrazolium, phagocytosis, ATP in polymorphonuclear leukocytes, chemoluminescence, $\mathrm{pH}$, lysozyme and $\beta$-glucuronidase, were compared after $0 \mathrm{~h}$ and $24 \mathrm{~h}$ of storage, for a paired sample (i.e. with the additive tested) and a control (i.e. without the additive tested).

Eleven parameters were studied (see tab. 1), and the experiment was performed five times.

\section{1) Enzymes \\ Lysozyme: EC 3.2.1.17}

$\beta$-Glucuronidase: EC 3.2.1.31 
Tab. 1. Results at $24 \mathrm{~h}$ of storage. The results are expressed in the form of the mean \pm standard deviation.

\begin{tabular}{|c|c|c|c|c|}
\hline Parameters & Time & Additives & Chemotaxis (mm) & Random migration (mm) \\
\hline $\mathrm{HCO}_{3}^{-}$ & $\begin{array}{l}0 \mathrm{~h} \\
24 \mathrm{~h}\end{array}$ & $\begin{array}{l}\text { without additives } \\
\text { with additives } \\
\text { without additives } \\
\text { with additives }\end{array}$ & $\begin{array}{l}1.93 \pm 0.07 \\
1.94 \pm 0.10 \\
0.16 \pm 0.07 \\
0.68 \pm 0.13\end{array}$ & $\begin{array}{l}0.96 \pm 0.04 \\
1.08 \pm 0.07 \\
0.13 \pm 0.10 \\
0.35 \pm 0.08\end{array}$ \\
\hline Glucose & $\begin{array}{l}0 \mathrm{~h} \\
24 \mathrm{~h}\end{array}$ & $\begin{array}{l}\text { without additives } \\
\text { with additives } \\
\text { without additives } \\
\text { with additives }\end{array}$ & $\begin{array}{l}1.90 \pm 0.16 \\
2.04 \pm 0.14 \\
0.86 \pm 0.07 \\
1.08 \pm 0.12\end{array}$ & $\begin{array}{l}0.96 \pm 0.08 \\
1.03 \pm 0.05 \\
0.46 \pm 0.06 \\
0.53 \pm 0.08\end{array}$ \\
\hline Calcium & $\begin{array}{l}0 \mathrm{~h} \\
24 \mathrm{~h}\end{array}$ & $\begin{array}{l}\text { without additives } \\
\text { with additives } \\
\text { without additives } \\
\text { with additives }\end{array}$ & $\begin{array}{l}2.12 \pm 0.20 \\
2.04 \pm 0.18 \\
1.12 \pm 0.07 \\
0.40 \pm 0.07\end{array}$ & $\begin{array}{l}1.03 \pm 0.11 \\
0.98 \pm 0.07 \\
0.59 \pm 0.12 \\
0.26 \pm 0.04\end{array}$ \\
\hline ATP & $\begin{array}{r}0 \mathrm{~h} \\
24 \mathrm{~h}\end{array}$ & $\begin{array}{l}\text { without additives } \\
\text { with additives } \\
\text { without additives } \\
\text { with additives }\end{array}$ & $\begin{array}{l}2.24 \pm 0.24 \\
2.21 \pm 0.28 \\
1.10 \pm 0.06 \\
1.40 \pm 0.12\end{array}$ & $\begin{array}{l}1.10 \pm 0.18 \\
1.10 \pm 0.16 \\
0.58 \pm 0.02 \\
0.68 \pm 0.07\end{array}$ \\
\hline Agitation & $\begin{array}{l}0 \mathrm{~h} \\
24 \mathrm{~h}\end{array}$ & $\begin{array}{l}\text { without additives } \\
\text { with additives } \\
\text { without additives } \\
\text { with additives }\end{array}$ & $\begin{array}{l}1.99 \pm 0.13 \\
2.04 \pm 0.12 \\
1.39 \pm 0.05 \\
1.30 \pm 0.08\end{array}$ & $\begin{array}{l}1.00 \pm 0.04 \\
1.01 \pm 0.06 \\
0.68 \pm 0.07 \\
0.62 \pm 0.04\end{array}$ \\
\hline Darkness & $\begin{array}{l}0 \mathrm{~h} \\
24 \mathrm{~h}\end{array}$ & $\begin{array}{l}\text { without additives } \\
\text { with additives } \\
\text { without additives } \\
\text { with additives }\end{array}$ & $\begin{array}{l}2.02 \pm 0.11 \\
1.99 \pm 0.14 \\
1.22 \pm 0.04 \\
1.36 \pm 0.04\end{array}$ & $\begin{array}{l}0.97 \pm 0.04 \\
1.00 \pm 0.07 \\
0.59 \pm 0.01 \\
0.64 \pm 0.04\end{array}$ \\
\hline Ascorbic acid & $\begin{array}{l}0 \mathrm{~h} \\
24 \mathrm{~h}\end{array}$ & $\begin{array}{l}\text { without additives } \\
\text { with additives } \\
\text { without additives } \\
\text { with additives }\end{array}$ & $\begin{array}{l}2.42 \pm 0.40 \\
2.44 \pm 0.30 \\
1.62 \pm 0.03 \\
1.97 \pm 0.17\end{array}$ & $\begin{array}{l}1.22 \pm 0.23 \\
1.19 \pm 0.10 \\
0.85 \pm 0.07 \\
0.96 \pm 0.11\end{array}$ \\
\hline RPMI & $\begin{array}{l}0 \mathrm{~h} \\
24 \mathrm{~h}\end{array}$ & $\begin{array}{l}\text { without additives } \\
\text { with additives } \\
\text { without additives } \\
\text { with additives }\end{array}$ & $\begin{array}{l}2.60 \pm 0.38 \\
2.74 \pm 0.13 \\
2.15 \pm 0.12 \\
1.74 \pm 0.13\end{array}$ & $\begin{array}{l}1.30 \pm 0.22 \\
1.34 \pm 0.13 \\
1.08 \pm 0.08 \\
0.84 \pm 0.06\end{array}$ \\
\hline NADH/NADPH & $\begin{array}{r}0 \mathrm{~h} \\
24 \mathrm{~h}\end{array}$ & $\begin{array}{l}\text { without additives } \\
\text { with additives } \\
\text { without additives } \\
\text { with additives }\end{array}$ & $\begin{array}{l}1.62 \pm 0.06 \\
1.82 \pm 0.18 \\
1.18 \pm 0.06 \\
1.48 \pm 0.06\end{array}$ & $\begin{array}{l}0.84 \pm 0.12 \\
0.84 \pm 0.12 \\
0.68 \pm 0.08 \\
0.72 \pm 0.06\end{array}$ \\
\hline$\alpha$-Tocopherol & $\begin{array}{r}0 \mathrm{~h} \\
24 \mathrm{~h}\end{array}$ & $\begin{array}{l}\text { without additives } \\
\text { with additives } \\
\text { without additives } \\
\text { with additives }\end{array}$ & $\begin{array}{l}1.98 \pm 0.14 \\
1.88 \pm 0.22 \\
1.36 \pm 0.06 \\
1.58 \pm 0.06\end{array}$ & $\begin{array}{l}0.98 \pm 0.08 \\
1.02 \pm 0.16 \\
0.72 \pm 0.12 \\
0.76 \pm 0.08\end{array}$ \\
\hline Antibiotics & $\begin{array}{l}0 \mathrm{~h} \\
24 \mathrm{~h}\end{array}$ & $\begin{array}{l}\text { without additives } \\
\text { with additives } \\
\text { without additives } \\
\text { with additives }\end{array}$ & $\begin{array}{l}2.12 \pm 0.22 \\
2.08 \pm 0.06 \\
1.68 \pm 0.06 \\
1.88 \pm 0.06\end{array}$ & $\begin{array}{l}1.16 \pm 0.08 \\
1.02 \pm 0.12 \\
0.82 \pm 0.12 \\
0.88 \pm 0.06\end{array}$ \\
\hline
\end{tabular}

\subsubsection{8 h preservation (assay XII)}

For this assay, the polymorphonuclear leukocyte functions studied were the same as those tested during $24 \mathrm{~h}$ preservation assay. These functions were measured after $0 \mathrm{~h}, 24 \mathrm{~h}$ and $48 \mathrm{~h}$ of preservation. The last storage medium used in the previous assays was taken as a new basal medium (with bicarbonate buffer, glucose, ATP, ascorbic acid, $\alpha$-tocopherol acetate, $\mathrm{NADH}, \mathrm{NADPH}$, amikacin and ampicillin; in the absence of light and agitation). The storage medium was rebuffered after $24 \mathrm{~h}$ with $10 \mu \mathrm{l}$ of $900 \mathrm{mmol} / \mathrm{l}$ bicarbonate buffer per $\mathrm{ml}$ of storage medium, in order to obtain in final concentration of sodium bicarbonate of $9 \mathrm{mmol} / \mathrm{l}$.

The control assay was not supplemented with these compounds.

This experiment was performed five times.

\subsubsection{6 h preservation (assay XIII)}

For this assay, chemotaxis was measured after $0 \mathrm{~h}, 24 \mathrm{~h}, 48 \mathrm{~h}$, $72 \mathrm{~h}$ and $96 \mathrm{~h}$ of preservation.

The storage medium (Plasmion ${ }^{\circledR}$ ) was supplemented on each day of storage $(0 \mathrm{~h}, 24 \mathrm{~h}, 48 \mathrm{~h}$ and $72 \mathrm{~h})$ with $10 \mu \mathrm{l}$ of each of the solutions of the different additives used in assay XII per $\mathrm{ml}$ of storage medium, in order to obtain final concentration of these substances as indicated above.

The control contained no additive.

This experiment was performed eight times.

\subsection{Method of analysis of the results}

Statistical comparisons for all assays were made using the nonparametric Wilcoxon test. 


\section{Results}

For all the assays, the temperature of storage was $25 \pm 2{ }^{\circ} \mathrm{C}$ and the polymorphonuclear leukocytes represented $69 \pm 20 \%$ of the leukocytes (mean \pm standard deviation). The endotoxin test was negative for all assays.

\section{1. $24 \mathrm{~h}$ preservation (assay I to XI)}

Leukocyte, polymorphonuclear leukocyte, erythrocyte and platelet counts were $6.7 \pm 1.8 \times 10^{9} / 1,4.5$ $\pm 1.6 \times 10^{9} / 1,32 \pm 10 \times 10^{9} / 1$ and $39 \pm 16 \times 10^{9} / 1$, respectively (mean \pm standard deviation).

At $0 \mathrm{~h}$ and $24 \mathrm{~h}$ of preservation, the results for chemotaxis and random migration are presented in table 1 .
At $0 \mathrm{~h}$ of storage, no significant difference (for all studied functions) was observed between media without additives studied and media with additives, except for the $\mathrm{pH}$ level in assay I. $(\mathrm{p}<0.005)$. The significant differences, for all functions studied, between media without additives studied and media with additives $(\mathrm{p}<0.05)$ after $24 \mathrm{~h}$ of storage are shown in table 2.

\section{2. $48 \mathrm{~h}$ preservation (assay XII)}

Leukocyte, polymorphonuclear leukocyte, erythrocyte and platelet counts were $7.8 \pm 2.0 \times 10^{9} / 1,5.9$ $\pm 1.8 \times 10^{9} / 1,50 \pm 30 \times 10^{9} / 1$ and $36 \pm 17 \times 10^{9} / 1$, respectively (mean \pm standard deviation).

The results for all functions studied after $0 \mathrm{~h}, 24 \mathrm{~h}$ and $48 \mathrm{~h}$ of preservation are presented in table 3.

Tab. 2. Significant results at $24 \mathrm{~h}$ of storage.

\begin{tabular}{|c|c|c|c|c|}
\hline Assay & Improvement & $\mathrm{P}$ & Deterioration & $\mathbf{P}$ \\
\hline $\mathrm{I}: \mathrm{HCO}_{3}^{-}$ & $\begin{array}{l}\text { chemotaxis, nitroblue } \\
\text { tetrazolium, pH, lysozyme } \\
\text { random migration } \\
\text { adenosine triphosphate, } \\
\beta \text {-glucuronidase } \\
\text { phagocytosis }\end{array}$ & $\begin{array}{l}<0.005 \\
<0.01 \\
<0.025 \\
<0.05\end{array}$ & $\begin{array}{l}\text { non significative } \\
\text { non significative } \\
\text { non significative } \\
\text { non significative }\end{array}$ & $\begin{array}{l}- \\
- \\
-\end{array}$ \\
\hline II: Glucose & $\begin{array}{l}\text { chemotaxis, phagocytosis } \\
\text { nitroblue tetrazolium }\end{array}$ & $\begin{array}{l}<0.025 \\
<0.05\end{array}$ & $\begin{array}{l}\text { non significative } \\
\text { non significative }\end{array}$ & - \\
\hline III: Calcium & $\begin{array}{l}\text { non significative } \\
\text { non significative } \\
\text { non significative }\end{array}$ & $\overline{-}$ & $\begin{array}{l}\text { chemotaxis, random migration } \\
\text { nitroblue tetrazolium, lysozyme, phag- } \\
\text { ocytosis, lysozyme, } \beta \text {-glucuronidase } \\
\text { chemoluminescence } \\
\text { adenosine triphosphate }\end{array}$ & $\begin{array}{l}<0.005 \\
<0.01 \\
<0.05\end{array}$ \\
\hline $\begin{array}{l}\text { IV: Adenosine } \\
\text { triphosphate }\end{array}$ & $\begin{array}{l}\text { chemotaxis } \\
\text { random migration } \\
\text { nitroblue tetrazolium }\end{array}$ & $\begin{array}{l}<0.005 \\
<0.025 \\
<0.05\end{array}$ & $\begin{array}{l}\text { non significative } \\
\text { non significative } \\
\text { non significative }\end{array}$ & $\begin{array}{l}- \\
-\end{array}$ \\
\hline V: Agitation & $\begin{array}{l}\text { non significative } \\
\text { non significative }\end{array}$ & - & $\begin{array}{l}\text { nịtroblue tetrazolium, } \\
\text { lysozyme } \\
\beta \text {-glucuronidase }\end{array}$ & $\begin{array}{l}<0.025 \\
<0.01\end{array}$ \\
\hline VI: Darkness & chemotaxis & $<0.025$ & non significative & - \\
\hline VII: Ascorbic acid & $\begin{array}{l}\text { chemotaxis, nitroblue } \\
\text { tetrazolium } \\
\beta \text {-glucuronidase }\end{array}$ & $\begin{array}{l}<0.05 \\
<0.025\end{array}$ & $\begin{array}{l}\text { non significative } \\
\text { non significative }\end{array}$ & - \\
\hline VIII: RPMI & $\begin{array}{l}\text { non significative, } \\
\text { non significative }\end{array}$ & $\begin{array}{l}- \\
-\end{array}$ & $\begin{array}{l}\text { chemotaxis, adenosine triphosphate, } \\
\beta \text {-glucuronidase } \\
\text { random migration, phagocytosis }\end{array}$ & $\begin{array}{l}<0.005 \\
<0.025\end{array}$ \\
\hline $\begin{array}{l}\text { IX: Nicotinamide adenine } \\
\text { dinucleotide/ } \\
\text { nicotinamide adenine } \\
\text { dinucleotide phosphate }\end{array}$ & chemotaxis & $<0.05$ & non significative & - \\
\hline$X: \alpha$-Tocopherol & chemotaxis & $<0.05$ & non significative & - \\
\hline XI: Antibiotics & chemotaxis, chemoluminescence & $<0.05$ & non significative & - \\
\hline
\end{tabular}




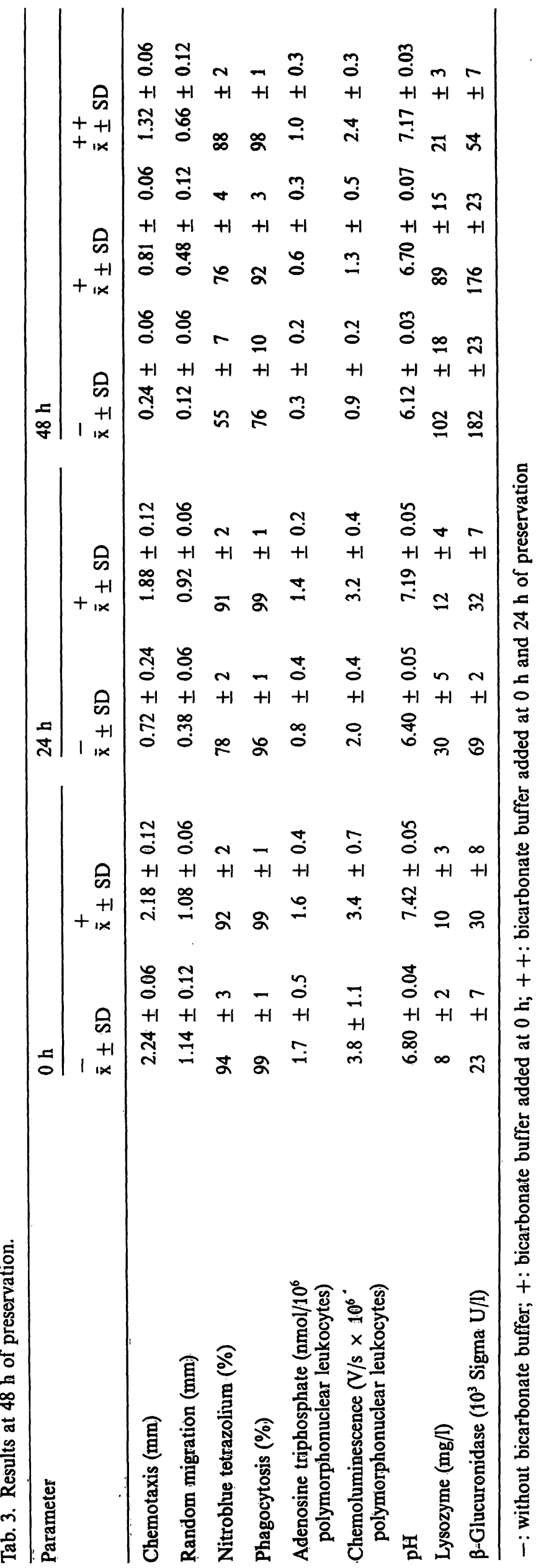

After $48 \mathrm{~h}$ of preservation, we observed several significant improvements with the rebuffered storage medium: a significance of $\mathrm{p}<0.001$ for $\mathrm{pH}$ level, lysozyme and $\beta$-glucuronidase release, of $p<0.01$ for chemotaxis, nitroblue tetrazolium and chemoluminescence, and of $\mathrm{p}<0.05$ for phagocytosis.

\section{3. $96 \mathrm{~h}$ preservation (assay VIII)}

Leukocyte, polymorphonuclear leukocyte, erythrocyte and platelet counts were $5.8 \pm 1.2 \times 10^{9} / 1,4.2$ $\pm 1.2 \times 10^{9} / 1,16 \pm 7 \times 10^{9} / 1,27 \pm 11 \times 10^{9} / 1$ respectively (mean \pm standard deviation).

Chemotaxis maintenance at $0 \mathrm{~h}, 24 \mathrm{~h}, 48 \mathrm{~h}, 72 \mathrm{~h}$ and $96 \mathrm{~h}$ of preservation is presented in table 4 .

Tab. 4. Chemotaxis maintenance at $0 \mathrm{~h}, 24 \mathrm{~h}, 48 \mathrm{~h}, 72 \mathrm{~h}$ and $96 \mathrm{~h}$ of preservation.

\begin{tabular}{|c|c|c|c|c|}
\hline \multirow[t]{2}{*}{$\begin{array}{l}\text { Storage } \\
\text { time }(h)\end{array}$} & \multicolumn{2}{|c|}{$\begin{array}{l}\text { Chemotaxis }(\mathrm{mm}) \\
(\overline{\mathrm{x}} \pm \mathrm{SD})\end{array}$} & \multicolumn{2}{|c|}{$\begin{array}{l}\text { Chemotaxis } \\
\text { maintenance }(\%)\end{array}$} \\
\hline & - & + & - & + \\
\hline 0 & $1.72+0.34$ & $1.75 \pm 0.39$ & 100 & 100 \\
\hline 24 & $0.72 \pm 0.32$ & $1.42 \pm 0.29$ & 42 & 83 \\
\hline 48 & $0.25 \pm 0.19$ & $1.03 \pm 0.17$ & 15 & 59 \\
\hline 72 & $0.08 \pm 0.14$ & $0.70 \pm 0.15$ & 5 & 46 \\
\hline 96 & $0.00 \pm 0.00$ & $0.36 \pm 0.14$ & 0 & 20 \\
\hline
\end{tabular}

$\mathrm{x} \pm \mathrm{SD}:$ mean \pm standard deviation

$+:$ with additives; - : without additives

The decrease of chemotaxis during $96 \mathrm{~h}$ preservation for the medium with additives, and without additives, is shown in figure 1.

At $0 \mathrm{~h}$ of preservation, chemotaxis was not significantly improved by the additives.

Compared with controls, chemotaxis maintenance was significantly improved by the additives at $24 \mathrm{~h}$ $(\mathrm{p}<0.05), 48 \mathrm{~h}(\mathrm{p}<0.001), 72 \mathrm{~h}(\mathrm{p}<0.001)$ and $96 \mathrm{~h}(\mathrm{p}<0.001)$.

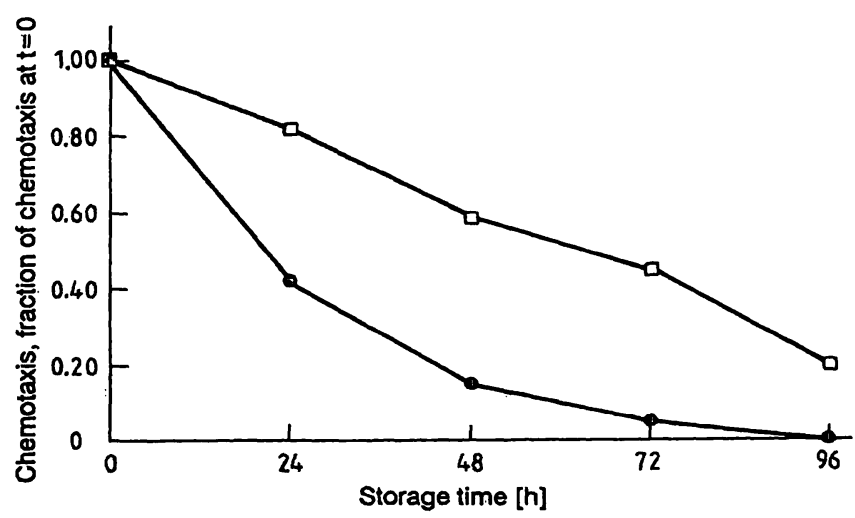

Fig. 1. Chemotaxis during storage.

$\square:$ with additives

- : without additives 
We also observed that during storage without additives, chemotaxis was significantly impaired after $24 \mathrm{~h}$ $(p<0.01)$. Again, using storage medium with additives, chemotaxis was not significantly decreased during the first $24 \mathrm{~h}$ of preservation, yet it was significantly impaired $(p<0.001)$ after $48 \mathrm{~h}$.

\section{Discussion}

\subsection{The choice of the storage medium}

We have chosen Plasmion ${ }^{\circledR}$ as the storage medium because an injectable medium such as Plasmion ${ }^{\circledR}$ would be appropriate if the polymorphonuclear leukocytes were subsequently used clinically. Other commonly used media such as RPMI are not injectable. Some authors obtain excellent results with RPMI supplemented with bicarbonate buffer, glucose and albumin $(1,16)$.

We also preferred a synthetic medium with a known composition rather than autologous plasma or glucose or bicarbonate-supplemented cell media.

To our knowledge, the use of Plasmion ${ }^{\circledR}$ as storage medium has not been mentioned in the literature.

\subsection{Purpose of the polymorphonuclear leu- kocyte functions studied}

Chemotaxis and random migration were measured because chemotaxis is the most sensitive indicator of polymorphonuclear leukocytes during storage $(2-4)$. The nitroblue tetrazolium reduction test (with phagocytosis of latex particles) and chemoluminescence were performed to study the oxidative metabolism of polymorphonuclear leukocytes during storage. Intragranulocytic ATP and storage medium $\mathrm{pH}$ were measured to study the energetic state of polymorphonuclear leukocytes, in relation to the glycolytic pathway. Release of lysozyme (primary and specific granules control) and $\beta$-glucuronidase (primary granule control) into the storage medium was measured to study the polymorphonuclear leukocyte degranulation during storage.

\section{3. $24 \mathrm{~h}$ preservation (assays I to $\mathrm{XI}$ )}

The purpose of our study at $24 \mathrm{~h}$ of preservation was to estimate the effect of different additives on polymorphonuclear leukocyte functions.

It is known that an important parameter that impairs polymorphonuclear leukocyte functions is the decrease of $\mathrm{pH}$ below 7.0 during storage $(2-4,10)$. That is why the addition of $15 \mathrm{mmol} / \mathrm{l}$ bicarbonate final concentration to all units of granulocyte concen- trate was recommended by Lane \& Lamkin in 1984 (10). After $24 \mathrm{~h}$ storage, when the $\mathrm{pH}$ level drops below 7.0, the polymorphonuclear leukocytes functions were strongly impaired (especially chemotaxis) and macroscopic clumps were observed. These results are consistent with the relevant literature $(2-4,10)$. The use of bicarbonate buffer limits this fall of $\mathrm{pH}$, which is due to lactic acid release by polymorphonuclear leukocytes (assay I), and this effect of bicarbonate was also noticed when the bicarbonate buffer was added after $24 \mathrm{~h}$ of storage (assay XII). Maintenance of the $\mathrm{pH}$ close to 7.4 may allow storage over a longer period of time (maybe several days).

Chemotaxis maintenance was improved by glucose at physiological concentrations. This is probably due to an increase at ATP generation by the glycolytic pathway, since chemotaxis is an energy-dependent phenomenon. These results are consistent with the relevant literature $(2-4,7)$. For the first time, a striking relationship was noticed between the level of neutrophil ATP and the chemotaxis of stored polymorphonuclear leukocytes $(11-13)$. However, the ATP depletion induced by the 2-deoxyglucose enhances chemotaxis, but not random migration, and seems to indicate that the previously reported correlation between ATP depletion and chemotaxis impairment is not causally related (14). In our study, ATP supplementation significantly improves chemotaxis. ATP, which does not cross membranes, may have an indirect effect in the improvement of chemotaxis, e.g. action of phosphate, adenine, or adenosine, or binding of ATP on a membrane receptor with release of a second messenger?

Calcium impairs many polymorphonuclear leukocyte functions, with macroscopic clump formation. This divalent cation could speed up leukocyte aggregation, leading to irreversible damage. This is consistent with current literature (5).

The agitation system used (similar to those used for platelet storage) does not improve polymorphonuclear leukocyte preservation; in fact it has the opposite effect. This is consistent with the relevant literature (2-4), but contradicts one report that chemotaxis was best maintained in polymorphonuclear leukocytes that were agitated (15).

The beneficial action of ascorbic acid might be explained by its reducing properties (elimination of oxygen radicals noxious to polymorphonuclear leukocyte storage?). The improvement of preservation due to $\alpha$-tocopherol acetate may be explained by a synergistic effect between this vitamin and ascorbic acid, leading to an effective antioxidation action. To our knowledge, these vitamins have not been previously 
used for polymorphonuclear leukocytes storage. Ginsburg found that NADPH supplementation may reactivate superoxide generation in leukocytes (6). It seems that a relatively reducing storage medium may be successful for polymorphonuclear leukocyte storage, which is in accordance with current literature (6).

The two antibiotics we used were chosen because of their broad spectrum of activity (Gram-negative bacteria for amikacin; Gram-negative and Gram-positive bacteria for ampicillin), and therefore to limit bacterial contamination of the storage medium. They also improve polymorphonuclear leukocyte chemotaxis and chemoluminescence.

Darkness seems to reduce polymorphonuclear leukocyte activation during storage. To our knowledge, such an influence has not been studied.

\section{4. $48 \mathrm{~h}$ and $96 \mathrm{~h}$ preservation}

The experiments at $48 \mathrm{~h}$ and $96 \mathrm{~h}$ of preservation had the purpose of studying more particularly chemotaxis, this function being to our view the most important.

During the $48 \mathrm{~h}$ preservation, satisfactory results were obtained after $24 \mathrm{~h}$ of storage, when chemotaxis was $82 \%$ of its starting value. This result is lower than, but close to value of $94 \%$ obtained by Glasser (16).

Chemotaxis was $60 \%$ of the starting value after $48 \mathrm{~h}$ of storage. Glasser also reported $60 \%$ (16). This author does not buffer the $\mathrm{pH}$ level of the RPMI storage medium after $24 \mathrm{~h}$ of preservation (16).

The $96 \mathrm{~h}$ preservation assay gives nearly the same result for chemotaxis maintenance as the previous one (assay XII): $83 \%$ versus $82 \%$ after $24 \mathrm{~h}$ storage; $59 \%$ versus $60 \%$ after $48 \mathrm{~h}$ storage. These results confirm that the most important additive is probably bicarbonate buffer.

In our experimental model, after $72 \mathrm{~h}$ of preservation, chemotaxis was $46 \%$ of the starting value, whereas in Glasser's model it was $15 \%$.

\section{References}

1. Béaud, M., Schooneman, F., Girot, M. \& Vigneron, C. (1981) Qualités fonctionnelles des polynucléaires séparés par cytaphérèse sur Haemonetics 30. Path. Biol. 29, 89-93.

2. Glasser, L., Lane, T. A., Mac Cullough, J. \& Price, T. (1983) Neutrophil concentrates: functional considerations, storage and quality control. J. Clin. Apheresis. 1, 179184.

3. Glasser, L., (1982) Liquid storage of granulocytes. Prog. Clin. Biol. Res. 88, $31-37$.

4. Mac Cullough, J. (1980) Liquid preservation of granulocytes. Transfusion 20,129-137.
After $96 \mathrm{~h}$ of preservation, chemotaxis maintenance is better than that observed with Glasser's model after $72 \mathrm{~h}(20 \%$ versus $15 \%)$.

We also observed that while chemotaxis of polymorphonuclear leukocytes decreased exponentially in the absence of additives, the decrease was much less marked and it was linear in their presence (fig. 1). Therefore, the additives consumed each day by polymorphonuclear leukocytes should be replaced daily. This procedure leads to a better maintenance of polymorphonuclear leukocyte functions, particularly chemotaxis.

The sterility of the storage medium is crucial for storage over several days. Antibiotic supplementation limits bacterial contamination, but all the additions must absolutely be sterile.

\section{Conclusion}

Use of the Plasmion ${ }^{\boxplus}$ medium for polymorphonuclear leukocytes offers the advantage over RPMI that it is injectable. Its chemical composition is fully known, unlike autologous plasma or cellular culture media.

Plasmion ${ }^{\oplus}$ needs many additives (bicarbonate buffer, glucose, ATP, vitamins $\mathrm{C}$ and $\mathrm{E}, \mathrm{NADH}$ and NADPH, ampicillin and amikacin), for an efficient polymorphonuclear leukocyte preservation. The model described gives relatively good results for chemotaxis maintenance, even after four days, supplements being added on each day of storage, and strict sterile conditions being maintained.

Various technical solutions can be considered, such as the addition of smaller packs containing additives which could be linked to the polymorphonuclear leukocytes after a suitable period of time. All these projects will be more completely considered in further investigations.
5. Contreras, T. J., Hunt, S. M., Lionetti, F. J. \& Valeri, C. R. (1978) Preservation of human granulocytes III Liquid preservation studied by electronic sizing. Transfusion 18 , 46-53.

6. Ginsburg, I., Borinski, R. \& Pabst, M. (1985) NADPH and "cocktails" containing polyarginine reactivate superoxide generation in leukocytes by membrane damaging agents. Inflammation 9, 341-362.

7. Glasser, L., Fiederlein, R. L. \& Huestis, D. W. (1985) Granulocytes concentrates: glucose concentrations and glucose utilization during storage at $22^{\circ} \mathrm{C}$. Transfusion 25 , $68-69$. 
8. Nelson, R. D., Mac Cormack, R. T. \& Fiegel, R. D. (1978) Chemotaxis of human granulocytes under agarose. In: Leukocyte chemotaxis: methods, physiology and clinical implications (Gallin, J. I. \& Quie, P. G., eds.) pp. 25-32, Raven Press, New York.

9. Thore, A. (1979) Technical aspects of the bioluminescent firefly assay of ATP. Science Tools $26,30-34$.

10. Lane, T. A. \& Lamkin, G. E. (1984) Hydrogen ion maintenance improves the chemotaxis of stored granulocytes. Transfusion 24, $231-237$.

11. Lane, T. A. \& Lamkin, G. E. (1982) Defective energy metabolism in stored granulocytes. Transfusion $22,368-$ 373.

12. Mac Cullough, J. \& Weiblen, B. J. (1979) The relationship of granulocyte ATP to chemotactic response during storage. Transfusion 19, 764-767.
13. Mann, J. S., Renwick, A. G. \& Holgate, S. T. (1986) Release of adenosine and its metabolites from activated human leukocytes. Clin. Sci. 70, 461-468.

14. Lane, T. A. \& Lamkin, G. E. (1984) A reassseșsment of the energy requirement for neutrophil migration: adenosine triphosphate depletion enhances chemotaxis. Blood 64, $986=993$.

15. Miyamoto, M. \& Sasakawa, S. (1987) Studies on granulocyte preservation III Effect af agitation on granulocytes concentrates. Transfusion 27, 165-166.

16. Glasser, L. \& Fiederlein, R. L. (1984) The effect of platelets and red cells on granulocytes concentrates stored at $22^{\circ} \mathrm{C}$. Transfusion 24, 310-315.

Pr. C. Vigneron

Centre régional de transfusion sanguine Service de Chimie Hématologique

Avenue de Bourgogne

F-54500 Vandœuvre-les-Nancy 